\title{
ISLAM IN INDONESIA'S FOREIGN POLICY, 1945-1949
}

\author{
Kevin W. Fogg \\ Oxford Centre for Islamic Studies, United Kingdom \\ email:kevin.fogg@history.ox.ac.uk
}

\section{Abstract}

Although most policy studies argue there has been no influence of Islam on Indonesia's foreign policy, the foreign relations of the Republic of Indonesia during the revolution for independence provide a counter-example. Because of the greater role for society in conducting, rather than just influencing, foreign relations, Islam was used as a key element in Indonesia's diplomatic efforts in the Arab world between 1945 and 1949. This led to several key, early successes for Indonesia on the world stage, but changing circumstances meant that relations with the Arab world and thus the place of Islam in foreign policy were no longer prominent from 1948.

Meskipun sebagian besar studi mengenai kebijakan luar negeri Indonesia menyatakan tidak adanya pengarub Islam dalam hal tersebut, kebijakan pada zaman revolusi kemerdekaan memperlibatkan adanya pengarub itu. Karena adanya peran yang lebih besar bagi masyarakat dalam membentuk dan menjalankan kebijakan pada saat itu, Islam digunakan sebagai sebuah elemen pokok dalam menjalankan bubungan diplomatik Indonesia dengan dunia Arab dari tabun 1945 bingga 1949. Hal ini mengarah ke beberapa keberbasilan awal yang menonjol bagi Indonesia di pentas internasional. Namun, sesuai dengan perubahan keadaan dunia sesudah tahun 1948, bubungan dengan dunia Arab menjadi tidak sepenting sebelumnya serta peranan Islam semakin memudar dan tidak lagi menjadi elemen kebijakan luar negeri.]

Keywords: foreign policy, Indonesia, Indonesian revolution, Egypt, Arab League 


\section{A. Introduction}

Indonesia, despite being the world's most populous Muslimmajority country, has since independence pursued a non-sectarian state and a non-sectarian national identity. Throughout the first half century of the country's independence --and especially throughout most of the Soeharto regime (1966-1998)-- Islam was not an ideology on which policy was based, an instrument of implementing policy, nor a rhetoric used to justify policy to the Indonesian public, even when it was occasionally used as a tool to win support for the regime. ${ }^{1}$ Although studies suggest a surge of Islamic influence on Indonesian politics in the last twenty years --seemingly more in form than in substance ${ }^{2}-$ there remains a strong narrative that Islam was not crucial to Indonesia's anti-colonial nationalism or early statehood and did not play a prominent role in the country's development. ${ }^{3}$

This idea of the irrelevance of Islam is particularly acute when looking at studies of Indonesia's foreign policy. The broad consensus in the literature and among diplomats is that Indonesia has not deployed Islam in its foreign affairs. Surin Pitsuwan, the Thai Muslim former Secretary-General of the Association of Southeast Asian Nations (ASEAN), has said in a recent speech, "We have not seen an element of Islam in the foreign policy of Indonesia since the beginning," meaning the country's founding in 1945. Similarly, the British-based scholar of Indonesian foreign policy Michael Leifer has written "it should be pointed out that Islam has never exercised a perceptible influence on the international outlook of the Indonesian state; nor has it enjoyed a place in the formal rhetoric of Indonesia's foreign policy." 5 'The same conclusion

${ }^{1}$ Robert W. Hefner, Civil Islam: Muslims and Democratization in Indonesia (Princeton: Princeton University Press, 2000).

2 Robin Bush, "Regional Sharia Regulations in Indonesia: Anomaly or Symptom?", in Expressing Islam Religious Life and Politics in Indonesia., ed. by Greg Fealy and Sally White (Singapore: Institute of Southeast Asian Studies (ISEAS), 2008); Merle Calvin Ricklefs, Islamisation and Its Opponents in Java: A Political, Social, Cultural and Religious History, c. 1930 to Present (Singapore: NUS Press, 2012), p. 259.

3 R.E. Elson, "Absent at the Creation: Islamism's Belated, Troubled Engagement with Early Indonesian Nationalism", in Anthony Reid and the Study of the Southeast Asian Past, ed. by Geoff Wade and Li Tana (Singapore: Institute of Southeast Asian Studies, 2012), pp. 303-35.

${ }^{4}$ Surin Pitsuwan, "The ASEAN Community 2015: Challenges and Opportunities for the Muslims of Southeast Asia", lecture at Oxford University, 28 Jan 2013.

${ }^{5}$ Michael Leifer, "The Islamic Factor in Indonesia's Foreign Policy: A Case of Functional Ambiguity", in Islam in Foreign Policy, ed. by Adeed Dawisha (Cambridge: 304

Al-Jāmi'ah, Vol. 53, No. 2, 2015 M/1437 H 
has also been drawn by Indonesian scholarship on the country's foreign relations. ${ }^{6}$ Even those Indonesian scholars who see a growing role for Islam in the country's rhetoric (although not necessarily policy) today have written that until recently the role of Islam has been only "as a constraining factor on a limited number of issues."

Instead of focusing on Islam, scholarship on Indonesia's foreign relations, especially in the earliest period of independence, has highlighted Indonesia's relationships with the United States, ${ }^{8}$ the United Nations, ${ }^{9}$ and, of course, the country's former colonial overlord, the Netherlands. ${ }^{10}$ Understandably, relations with these countries did not emphasize religion, and especially not Islam. When looking at relations between Indonesia and other Asian and African states, Dewi Fortuna Anwar argued that "Solidarity among developing countries took precedence over solidarity among Muslim countries as co-religionists per se." 11

The only caveat suggested by studies so far has been the nuanced argument of the Indonesian scholar Anak Agung Banyu Perwita. He has noted that although formal governmental policy has not prioritized Cambridge University Press, 1983), p. 148.

${ }^{6}$ Kirdi Dipoyudo, "Indonesia's Foreign Policy towards the Middle East and Africa", The Indonesian Quarterly, vol. 13, no. 4 (1985), pp. 474-85; this text does not specifically deny any Islamic connection, but it makes no mention of one, and never uses the words "Islam" or "Muslim." More clearly un-Islamic is the account written by the famous Balinese diplomat Ide Anak Agung Gde Agung, Twenty Years Indonesian Foreign Policy 1945-1965 (The Hague: Mouton, 1973).

7 Dewi Fortuna Anwar, "Foreign Policy, Islam and Democracy in Indonesia", Journal of Indonesian Social Sciences and Humanities, vol. 3 (2010), p. 47; This is also the position of Azyumardi Azra, "Islam in Indonesian Foreign Policy", in Indonesia, Islam, and Democracy: Dynamics in a Global Context (Jakarta: Solstice Publishing, 2006), pp. 89-111.

${ }^{8}$ Andrew Roadnight, United States Policy towards Indonesia in the Truman and Eisenhower Years (New York: Palgrave Macmillan, 2002); Robert J. McMahon, Colonialism and Cold War: The United States and the Struggle for Indonesian Independence, 1945-49 (Ithaca, NY: Cornell University Press, 1981); Paul F. Gardner, Shared Hopes, Separate Fears: Fifty Years of U.S.-Indonesia Relations (Boulder, CO: Westview Press, 1997); Frances Gouda and Thijs Brocades Zaalberg, American Visions of the Netherlands East Indies/Indonesia: US Foreign Policy and Indonesian Nationalism, 1920-1949 (Amsterdam: Amsterdam University Press, 2002).

9 Alastair M. Taylor, Indonesian Independence and the United Nations (London: Stevens, 1960); This is also the emphasis of the diplomatic elements in George McTurnan Kahin, Nationalism and Revolution in Indonesia (Itaca, NY: Cornell University Press, 1952).

${ }^{10}$ Jon M. Reinhardt, Foreign Policy and National Integration: The Case of Indonesia (New Haven, CT: Yale University Southeast Asia Studies, 1971).

11 Anwar, "Foreign Policy", p. 47. 
Islamic interests, societal pressures from Muslims and Muslim groups in the country have shaped and constrained the government's approach to certain issues. ${ }^{12}$ Perwita's observations focused on the New Order period, when foreign policy was managed with a strong hand by the Soeharto regime. It raises questions, though, about the possibility of greater societal influence on Indonesia's foreign policy and the impact this would have on the position of Islam. If society was able to insert Islam into foreign policy in a marginal way (as a prompt or constraint) in the Soeharto era --when the state was at its strongest-- one should look to other periods when society was stronger to provide a greater role for Islam. This also opens up broader questions of Indonesia's global position in the mid-twentieth century, including whether developing country solidarity was ideological or merely pragmatic, and how different sectors of the bureaucracy or wider society held different visions of trans-regional links in periods when society had more impact on policy.

This article will focus on just such a period: Indonesia's revolution for independence, from the proclamation of independence in August 1945 until the formal transfer of sovereignty from the Dutch in December 1949. This was an exceptional time because strong initiative taken by individuals and groups of Indonesians had a major impact on Indonesia's foreign policy, independent of the preference of the state's leaders. In this context, Indonesia had exceptionally strong diplomatic relationships with Arab countries in the Middle East. These relationships were forged on the rhetorical foundation of Islamic brotherhood and co-religionist solidarity. This case demonstrates that at the moment of greatest popular participation in Indonesia's foreign policy, Islam played an important role. This has broader implications for reconsidering the role of Islam in the early independent Indonesian sand the ways in which societal actions must be considered when evaluating the place of religion in the Indonesian state, especially at moments when society was strong and the state was weak.

The major limiting factor in the study of Indonesia's diplomatic history has been Indonesia's reticence to open the archives of its Ministry of Foreign Affairs. This non-disclosure is fuelled both by an understandable scepticism about disclosing information related to national security and international relations (even the Availability of Public Information Law of 2008 had sweeping exceptions related to

12 Anak Agung Banyu Perwita, Indonesia and the Muslim World: Islam and Secularism in the Foreign Policy of Soeharto and Beyond (Copenhagen: NIAS Press, 2007). 
perceived "security" topics) ${ }^{13}$ and by institutional inertia that cannot easily accommodate a change in mentality to open public archives. Because of the heavy societal participation during the revolution, however, many other sources describe aspects of diplomatic relations and the promotion of the Indonesian cause. Thus, this article establishes the role of Islam in Indonesia's foreign relations --in this case in the Middle East between 1945 and 1949-- from other archival collections, published sources, memoirs, oral histories, and contemporary news accounts.

During this period, Indonesia's priority (both for the state and societal groups) was seeking recognition of its independence from the Netherlands, after the former colonial power had re-invaded in the wake of the Second World War. Groups of Indonesians organized in Cairo, Mecca, and elsewhere to push Arab governments towards supporting the Indonesian cause. The efforts in Cairo were both particularly Islamic in content and particularly successful, leading to recognition by the Arab League and subsequently by Egypt and other Arab states. Recognition by these Arab states was important for Indonesia because this allowed them to internationalize the conflict, denying the Netherlands the ability to call the war in Indonesia an "internal" problem immune from international meddling.

Around 1948, the diplomatic situation changed to reflect new situations in both Indonesia and the Arab Middle East. In Indonesia, the nascent Republic was taking stronger control of foreign policy and chose to channel attention more towards international bodies (especially the UN) and major Western states. This led to a decline in Islamic appeals and connections. In the Arab Middle East, the crisis surrounding the creation of the state of Israel became the full focus of local governments, pulling them away from advocacy for Indonesia. As a result, Indonesian foreign policy downplayed Islam in the final years of the revolution, even as societal groups continued to work in Egypt and the Hejaz. In foreign affairs, as with other aspects of Indonesian policy, the increasing strength of the state caused the role of Islam to decline.

\section{B. The Background of the Indonesian Revolution}

The Dutch were intensively involved in trade in Southeast Asia from the seventeenth century onward, but from around 1820 their

${ }^{13}$ Undang-undang Keterbukaan Informasi Publik, no. 14 / 2008 (Law no. 14 of 2008), see especially chapter V on Classified Information, Article 17. 
exclusive trading zones and special treaties rapidly evolved into formal territorial colonialism. Circa 1911, they had consolidated political control over a vast archipelagic territory, which they called the Netherlands Indies. Stretching from Sumatra to Papua (with the exclusion of the Portuguese colony of East Timor), the borders established by Dutch imperialism later became the boundaries that defined Indonesian nationalism. The nationalist movement gained strength through the 1910s and 1920s, suffering fractures and setbacks into the 1930s but still captivating the attention of the native elites. This narrative of local challenges to Dutch authority was sharply interrupted in 1942, when the Japanese quickly conquered the whole territory and integrated it into their wartime Greater East Asia Co-Prosperity Sphere until 1945.

On August 17, 1945, just days after the unconditional surrender of the Japanese in the Second World War, Indonesia proclaimed its independence, in a speech by the two long-time leaders of the secular nationalist movement: Sukarno and Mohammad Hatta. Putting this proclamation into action was difficult, though. At this point, the dream of Indonesian independence was staunchly opposed by the former colonial power. At the end of the Second World War, the Netherlands declared its intention to keep the colony, enlisted the support of its European allies, and re-invaded Indonesia, which resulted in a four-year war to uphold Indonesian independence. This four-year war is known in Indonesia as the Revolution.

In Indonesia's Revolution, military conflicts on the ground dominated the popular experience, but were not the ultimate determinant of the outcome. ${ }^{14}$ Rather, Indonesia's independence reflected the decisive influence of international politics and new international institutions after World War II. As Samuel Crowl has noted, "Indonesians were the first colonial subjects to successfully use diplomacy as a weapon against a colonial power in an independence struggle." ${ }^{15}$ The new United Nations Organization took up Indonesia's case in plenary debates in 1947, and the UN-created "Committee of Good Offices" facilitated negotiations between Dutch and Indonesian representatives leading to the final

${ }^{14}$ For a still-unsurpassed account of the Indonesian revolution that balances on-the-ground military conflict with international diplomacy, see Kahin, Nationalism and Revolution.

15 Samuel E. Crowl, "Indonesia's Diplomatic Revolution: Lining Up for NonAlignment, 1945-1955", in Connecting Histories: Decolonization and the Cold War in Southeast Asia, 1945-1962 (Stanford, CA: Woodrow Wilson Center Press and the Stanford University Press, 2009), p. 238. 
settlement in 1949 .

In the new global context of international institutions, though, Indonesia stood in need of many kinds of international allies. ${ }^{16}$ Thus, the new government looked to both traditional and circumstantial friends for support in various ways. Other formerly colonized countries in the developing world came to Indonesia's aid in the UN discussions. India received much attention for being particularly supportive, but even Latin American countries helped support the Indonesian cause. ${ }^{17}$ Australia also played a key role as Indonesia's choice in the Committee of Good Offices. ${ }^{18}$ In many places, the diplomatic work on the Indonesian side to win such support from other countries was done by self-appointed individuals: Indonesians who happened to be present in foreign capitals when the Revolution broke out. This was the case in Australia, where Indonesians who had been interned in the country won over the support of the labor movement as a whole. ${ }^{19}$ Indonesians also took up the new country's cause in the United States, the Czech Republic, and in the Middle East. ${ }^{20}$ These Indonesians abroad could be students, as was the case for most in the Middle East, but they could also be traders, activists or laborers.

Amidst the various kinds of support received from around the world for the Indonesian Revolution, many early and concrete diplomatic steps were taken by Arab countries. Arab countries, of course, had a more long-standing connection with Indonesians, especially the centres

16 This idea is articulated particularly well in Ibid., pp. 238-57.

17 Kahin, Nationalism and Revolution, pp. 400, 16.

${ }^{18}$ For an account that highlights Indian and Australian contributions, see Crowl, "Indonesia’s Diplomatic Revolution". See also Stephen Gapps, "Black Armada: Australian Support for Indonesian Independence", Australian National Maritime Museum, http://stories.anmm.gov.au/blackarmada/, accessed 16 Feb 2016.

19 This has been described especially by the leader of the Indonesian activists in Australia at the time, Mohamad Bondan, Genderang Proklamasi di Luar Negeri, 1st edition (Jakarta: Pertjetakan Kawal, 1971); see also his wife's account, Molly Bondan, Spanning a Revolution: The Story of Mohamad Bondan and the Indonesian Nationalist Movement (Jakarta: Pustaka Sinar Harapan, 1992).

${ }^{20}$ Crowl, "Indonesia's Diplomatic Revolution”, p. 240; Mien Soedarpo, Reminiscences of the Past, vol. 2, ed. by Siti Nuraini Barnett (Jakarta: Sejati Foundation with PT Gramedia Widiasarana Indonesia, 1997); Arsip Nasional Republik Indonesia, Koleksi RA3 “Djogdja Documenten 1945-1949," no. 306: "Surat-surat dari Perwakilan Republik Indonesia di beberapa negara." 
of traditional Islamic learning in Cairo and Mecca. ${ }^{21}$ Into the twentieth century, Islamic reformism from Cairo helped to kick off modern politics and religious activism in Indonesia. ${ }^{22}$ The increasing connectedness of the Islamic world in this period facilitated ever rising numbers of Indonesians going to the Middle East, and increasing numbers of Arabs in Indonesia, too. ${ }^{23}$ The majority of Indonesians in the Middle East went for the pilgrimage to Mecca, but many extended their sojourns for study, either in the Hijaz or in Cairo, and occasionally in other Arab centres of learning such as Baghdad. Being absent from the homeland, though, did not mean they were disconnected from it. In the 1920s and 1930s, Indonesian students in Cairo especially were active in nationalist organizations and publishing Malay-language journals about religious and political issues. ${ }^{24}$ Supra-ethnic, regional, Islamic solidarity forged in the Middle East among Indonesian Muslims transformed into a religious nationalism that ran alongside, but was not subsumed by, secular nationalism. ${ }^{25}$ There was also an awareness in the Arab world of Southeast Asian Muslims as part of the greater Islamic community jointly struggling towards modernity. For example, the classic 1931 treatise by Shakib Arslan, "The Causes of Our Decline," expounding on the position of Muslims in a world dominated by European Christians, was written in response to a question from an

${ }^{21}$ Christiaan Snouck Hurgronje, Mekeka in the Latter Part of the 19th Century: Daily Life, Customs and Learning, the Moslims of the East-Indian Archipelago (Leiden: Brill, 2007).

${ }^{22}$ Deliar Noer, The Modernist Muslim Movement in Indonesia, 1900-1942 (Singapore: Oxford University Press, 1973).

${ }^{23}$ R. Michael Feener, "New Networks and New Knowledge: Migrations, Communications and the Refiguration of the Muslim Community in the Nineteenth and Early Twentieth Centuries", in The New Cambridge History of Islam, ed. by Robert W. Hefner (Cambridge: Cambridge University Press, 2010), pp. 37-68; Eric Tagliacozzo, The Longest Journey: Southeast Asians and the Pilgrimage to Mecca: Southeast Asians and the Pilgrimage to Mecca (Oxford: Oxford University Press, 2013); Engseng Ho, The Graves of Tarim: Genealogy and Mobility across the Indian Ocean: Genealogy and Mobility across the Indian Ocean (Berkeley, CA: University of California Press, 2006); Natalie Mobini-Kesheh, The Hadrami Awakening: Community and Identity in the Netherlands East Indies, 1900-1942 (Ithaca, N.Y:: Cornell University Southeast Asia Program, 1999).

${ }^{24}$ William R. Roff, "Indonesian and Malay Students in Cairo in the 1920s", Indonesian, no. 9 (1970), pp. 73-87.

${ }^{25}$ Michael Francis Laffan, Islamic Nationhood and Colonial Indonesia: The Umma Below the Winds (London: Routledge, 2003). This scholarship on contributions to Indonesian nationalism from the Middle East has recently been tempered by Elson, "Absent at the Creation." 
Indonesian imam. ${ }^{26}$

With this foundation, it is no surprise that Arab countries in the Middle East were some of the early targets for Indonesian diplomatic efforts. The key theme in using Islam for Indonesia's diplomatic outreach was the motto of Islamic Brotherhood (Ar., ukbuwah Islamiyah). ${ }^{27}$ Islamic Brotherhood as a doctrine emphasizes the fellowship of all Muslims, joined through their shared religious beliefs, and the obligation for mutual help among them. This is notably different from pan-Islamism, another important ideology in the nineteenth and twentieth centuries, which sought a political unity of all Muslims under a single state with global reach. ${ }^{28}$ Islamic brotherhood, by contrast, emphasized the fraternal actions of individual Muslims and remained ambiguous towards state power; as such, it was the perfect ideology for societal groups abroad pushing other Muslims to support Indonesian independence. Societal groups were able to mobilize this ideology to gain the support of key Muslims in the Arab world. These Muslim leaders were then able to drive states and international organizations to action.

\section{Islam in Initial Public Relations by Societal Groups}

The societal groups that pioneered the Indonesian cause in the Middle East were student groups. Although many of these groups had been active as welfare or scholarly organizations in key centres of learning before the Second World War, their role transformed into lobbying organizations quickly in 1945. Islam was important within the groups, convincing members that Indonesian independence was an important goal, but also outside the groups, appealing to Middle Eastern Muslims. ${ }^{29}$

In 1945 when Indonesian independence was proclaimed, organizations of Southeast Asian Muslims were active across the

${ }^{26}$ Moch Nur Ichwan, "Differing Responses to an Ahmadi Translation and Exegesis: The Holy Qur'ân in Egypt and Indonesia”, Archipel, vol. 62, no. 1 (2001), pp. 149-50.

${ }^{27}$ Not to be confused with the religious-cum-political group in Egypt, the Muslim Brethren or Muslim Brotherhood (Ar. Ikhwän al-Muslimin).

${ }^{28}$ J.M. Landau, "Pan-Islamism," Encyclopaedia of Islam, ed. by P. Bearman, Th. Bianquis, C.E. Bosworth, E. van Donzel, and W.P. Heinrichs, (Leiden: Brill, 2014), http://referenceworks.brillonline.com/entries/encyclopaedia-of-islam-2/ pan-islamism-SIM_6069

${ }^{29}$ On ways in which Islam was an important basis to mobilize support for independence back in Indonesia, see Kevin William Fogg, "The Fate of Muslim Nationalism in Independent Indonesia”, PhD. Thesis (Yale University, 2012), pp. 159-70. Al-Jämi'ah, Vol. 53, No. 2, 2015 M/1437 H 
Middle East, many of them also benefitting from cooperation between Indonesian and Malayan students. In Egypt, the leading group was the Persatuan Pemuda Indonesia-Malaya (Perpindom, Union of IndonesianMalayan Youth), formed around a core of students but also with some graduates who were still resident in the city. ${ }^{30}$ According to a newspaper account in July 1946, based on interviews with returning sailors who had passed through Cairo on their journey back from the Netherlands, there were about 70 Indonesian students in Egypt who had stayed through the Second World War, struggling against food shortages and a lack of communication with their homeland. ${ }^{31}$ Saudi Arabia had by far the largest population of Indonesians in the Middle East --between 3,500 and 4,000 individuals at the start of the revolution ${ }^{32}-$ and the analogous collective there was called Persatuan Talabah Indonesia-Malaya (Pertindom, Union of Indonesian-Malayan Students). Iraq was a much smaller outpost, but still had its own group, the Majlis Kebangsaan Indonesia-Malaya (Makindom, National Council of Indonesia-Malaya), centred in Baghdad. ${ }^{33}$ One of the activists in Cairo compared these rag-tag student groups to the militias that were springing up to defend Indonesia's independence on the country's own soil at the time. ${ }^{34}$

Despite not being the largest, the group in Cairo was the most active in promoting Indonesian independence in the early years of the revolution. One of the leaders of Perpindom in Cairo was a young, ethnically-Minangkabau activist named M. Zein Hassan, and Hassan's memoir, written thirty years later, provides an important but partial account of Indonesia's diplomatic developments in the Middle East during the Revolution. This account is partial in two senses: first, it is (like any single historical document) incomplete --limited by his location in Cairo and inability to record every event; second, it is biased (i.e., not impartial) by very much taking the side of Perpindom and promoting the organization's role (and Hassan's own role) in diplomacy. This account, though, fits well with other extant sources to create a fuller picture of

${ }^{30}$ Perpindom was the heir and fusion of two earlier student organizations in Egypt: Nadi Pemoeda Indonesia dan Malaja and Djamijatoel Chairijah. See Tengkoe Jafizham, Studenten Indonesia di Mesir (Medan: Sinar Deli, 1939), pp. 75-6; Jafizham was present when this fusion occurred.

31 "Nasib Poetera2 Indonesia di Mesir dan Arab," Lasjkar (25 Jul 1946).

32 See the various estimates in Muhammad Zein Hassan, Diplomasi Revolusi Indonesia di Luar Negeri (Jakarta: Bulan Bintang, 1980), p. 35; "Nasib Poetera2 Indonesia".

33 On the organizations, see Ibid., p. 23.

34 Ibid., p. 20. 
what was happening on the ground. For example, the work Hassan reports of building solidarity among dockworkers on the Suez Canal (to hamper Dutch ships passing through this international passageway) fits very closely with the accounts given by sailors who had returned to Indonesia from the Middle East, ${ }^{35}$ and the description of a close working relationship with Azzam Pasha, secretary of the Arab League, was confirmed in the Indonesian press and in later accounts by Azzam Pasha himself. ${ }^{36}$

The activists in Indonesian associations across the Middle East initiated a public relations campaign soon after news of the proclamation of independence reached them in September 1945 (almost a full month after the proclamation itself because of Allied censorship on the issue).$^{37}$ The committee scrambled to put out information about Indonesia's independence struggle, even though they did not have full or accurate information themselves. This led to the publication of a book in Arabic, Indonesia ath-Thawrah (Indonesia in Revolution), with certain episodes completely fabricated, such as Sukarno's proclamation of independence in front of a massive crowd in Jakarta's central square (in fact, it happened before a small group at a house on a major thoroughfare). ${ }^{38}$

The first coordination between the various Indonesian organizations across the Middle East came in November 1945. Taking advantage of bajj season, leaders of Perpindom, Pertindom, and Makindom met in Mecca on November 13, to coordinate their efforts. They all agreed to follow the political program set in Cairo, because they saw Cairo as the diplomatic seat of the Arab world. ${ }^{39}$ After this face-to-face contact, the organizations were able to keep in touch with the help of the Iraqi ambassador in Cairo, who allowed the Indonesians to use the security of his diplomatic pouch for transferring messages safe from the prying eyes of the Dutch. ${ }^{40}$

${ }^{35}$ Compare Ibid., p. 224ff., and "Nasib Poetera2 Indonesia".

36 See a picture of Azzam Pasha, seemingly with Zein Hassan and his colleagues of Perpindom, in Hikmah (June 1949), p. 25; and the account in Ali Sastroamidjojo, Milestones on My Journey: The Memoirs of Ali Sastroamijoyo, Indonesian Patriot and Political Leader, ed. by Christiaan Lambert Maria Penders (St. Lucia, Queensland: University of Queensland Press, 1979), p. 152.

37 Hassan, Diplomasi Revolusi, p. 49.

38 Ibid., pp. 51-2. Hassan transliterates the book title as Indonesia as-Sairab; unfortunately, I have not been able to locate any original copy.

39 Ibid., p. 57.

40 Ibid., p. 33. 
As they began efforts aimed at increasing the profile of their national struggle, Indonesian groups frequently made use of Islamic symbols. For example, in the closing months of 1945, the Indonesian committees across the region convinced mosques around the Arab countries to hold special prayers for the "souls of the Indonesian martyrs of Surabaya," a major battle early in the war. ${ }^{41}$ A similar tactic was taken later, upon the death of a leading Islamic cleric in Surabaya, the Muhammadiyah leader K.H. Mas Mansur. The Cairo committee turned it into a propaganda point, "degrading the humanity of the Dutch and their English allies" that such a casualty could happen under their watch. ${ }^{42}$ Students in the organization reportedly "wrote in the local Egyptian newspapers, attended political meetings in Cairo and met important political figures to ask for their support for Indonesian independence." ${ }^{43}$ Throughout, they used Islam as a mobilizing factor. Presenting a message to Arab foreign ministers as the revolution began, Indonesian students had intentionally mentioned Islam when describing their country: Hassan spoke of Indonesia as a country of "70 million, among whom $90 \%$ consist of Muslims," or even as an "Eastern Islamic country." 4

To help their own public relations efforts, the Indonesians in Cairo created an organization to mobilize Arab voices in favour of Indonesian independence. This group, formed in October 1945, was called Lajnatud Difa' $i$ 'an Indonesia, or the Committee to Defend Indonesia. Its members included luminaries from Arab society, like 'Abd al-Raḥmān 'Azzām (often called Azzam Pasha in the Indonesian accounts), Secretary-General of the nascent Arab League, and Habib Bourguiba, future president of Tunisia. ${ }^{45}$ In circulating the Committee's goals to governments, the honorary head, Gen. Saleh Harb Pasha, repeatedly pointed to "Islamic brotherhood" as his motivating goal, showing the importance of this

${ }^{41}$ Ibid., p. 89.

42 Ibid., p. 275. For more information on the passing of Mas Mansur in the context of Indonesia, see oral history with Harsono Tjokroaminoto, interviewed by Wardiningsih Surjohardjo, Arsip Nasional Republik Indonesia, "Koleksi Sejarah Lisan”, 1982 no. 60, especially tape 28 on the revolutionary period.

43 These were the activities reported in interviews by Harun Nasution and Fu'ad Fakhruddin, two Indonesian students in Cairo at the time; Mona Abaza, Indonesian Students in Cairo: Islamic Education: Perceptions and Exchange (Paris: Association Archipel, 1994), p. 82.

${ }^{44}$ Quoted in Hassan, Diplomasi Revolusi, p. 42.

${ }^{45}$ Ibid., p. 62; Abaza, Indonesian Students in Cairo, p. 81. 
idea for diplomatic relations. ${ }^{46}$ Similarly, a former Egyptian ambassador to London, Dr. Hafiz Afifi Pasha, agreed to help lobby on behalf of the Indonesians to the United Nations meeting in Great Britain in 1946, reportedly inspired by the fact that Egyptians and Indonesians "had the same religion, traditions, and goals." ${ }^{\prime 7}$

The talking point of Islamic brotherhood was impressed on the Arab public by careful messaging on the part of the Indonesian students of Perpindom. When the first official Indonesian delegation was passing through the Middle East in April 1946 (on its way to and from negotiations in the Netherlands), the local committee encouraged them to use Islamic rhetoric and to push especially hard on the theme of Islamic Brotherhood, as the Indonesians in Cairo believed that this was the most effective strategy for drawing in the Arab world. ${ }^{48}$ This was not the only option available to them; to internationalize the war in Indonesia the delegation could have played on anti-colonialism, nationalism, or anti-European sentiments, as New York Times articles of the era did, for example, to connect Egypt and Indonesia. ${ }^{49}$ Islamic brotherhood must have been a conscious and strategic emphasis, and it was an effective one to draw other sovereign states' interest and deny the Netherlands the excuse that Indonesia was an "internal matter" and thus prevent great power interference.

The effects of internationalization through Islamic rhetoric were felt particularly in Egypt. Egyptians participated in a boycott of Dutch ships, and even harassed and encircled Dutch ships passing through the Suez Canal to prevent them from boarding new supplies. ${ }^{50}$ By late September 1946, the Egyptian newspaper Al Ichwanoel Moeslimin (Muslim Brethren) editorialized in favour of recognizing the Indonesian Republic. ${ }^{51}$ Indonesian students reported that Egyptian political parties from across the political spectrum, from the nationalist Wafd through the socialist Misr al-Fatāh and even the Communists were working with them to

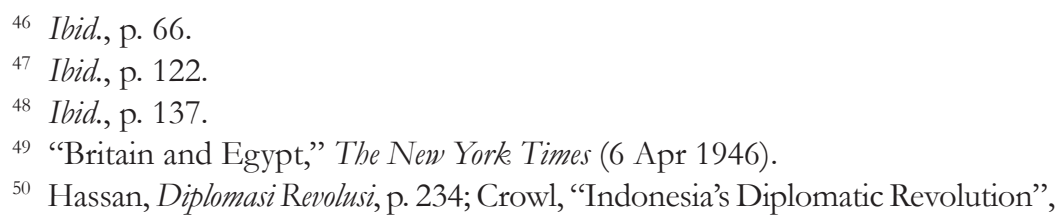
p. 242; Abaza, Indonesian Students in Cairo, p. 86.

51 “Akoeilah Repoeblik Indonesia: Desakan sk di Mesir," Lasjkar (11 November 1946). It is possible that the report was mistaken, and this urging came from the mass organization known as the Muslim Brotherhood, but the Brotherhood did have a newspaper subsidiary in this period. 
promote Indonesian independence. Despite working with a broad crosssection of society, the sympathies among the Indonesian students most commonly lay with the Muslim Brothers organization. ${ }^{52}$ Their most important support, though, came from the diplomatic community.

\section{Indonesia and the Arab League}

After the seeds had been sown by the Indonesian students in Cairo, the initiative to support Indonesia's independence was taken up by the diplomats and political leaders. However, it was not primarily Indonesian diplomats (Indonesia was still unable to send ambassadors abroad at this stage), but rather Arab diplomats, who moved forward on the issue --particularly diplomats from a newly emerging organization in Cairo.

The League of Arab States, more popularly known as the Arab League, was created as a supra-national organization only in $1944,{ }^{53}$ but it played an important role in the story of early Indonesian diplomacy. Because Indonesia's independence also came soon after the Arab League was created, it was also an early test case for the League's member states trying to assert influence internationally.

Arab League attention to the Indonesian issue began quite early. In a speech in the American University of Cairo on January 4, 1946, the Secretary-General assured his audience that the new organization was "defending justice and liberty everywhere, be it in Indonesia or in a defeated Germany." ${ }^{4}$ On April 8, 1946, less than nine months after Indonesia proclaimed independence, the Arab League issued its first resolution on the Indonesian national struggle. The text ran thus: "The Council seized an opportunity during the passage through Cairo of the Indonesian delegation going to Holland to declare its sympathy for Indonesia and its wish that it would secure full independence." ${ }^{55}$ This was just two days after it formally resolved to support Libyan independence,

52 Abaza, Indonesian Students in Cairo, p. 81, citing an interview with Yussuf Saad in Cairo, 4 Oct 1987. Yussuf Saad was an Indonesian student in Cairo in the 1940s, and he returned to work in the Indonesian embassy there much later.

53 Majid Khadduri, "The Arab League as a Regional Arrangement", The American Journal of International Law, vol. 40, no. 4 (1946), p. 765.

54 Abd al-Rahman Azzam, "The Arab League and World Unity", in Contemporary Arab Political Thought, ed. by Anouar Abdel Malek, trans. by Michael Pallis (London: Zed Press, 1983), p. 144.

${ }_{55}$ Resolution 45, Session 3, Schedule 9, 8 April 1946, as translated in Egyptian Society of International Law, Egypt and the United Nations (New York: Manhattan Publishing Company for the Carnegie Endowment for International Peace, 1957), p. 138. 
and still several months before the Council of the Arab League formally declared in favour of Tunisia or Morocco becoming independent from the French. Clearly, the Indonesian issue was at the forefront of its diplomatic thinking. ${ }^{56}$

Later that year, at the October 1946 meeting of the Arab League, the Secretary-General put forward the possibility of offering up the Arab League as a mediator in the conflict between the Indonesians and the Dutch. This motion seems not to have been taken forward. ${ }^{57}$ Further action came the next month, when the Council of the Arab League agreed in a unanimous vote of all seven states to a resolution: "The Council recommends to the members of the Arab League that they recognize Indonesia as an independent sovereign state." 58 This made the Arab League the first international body to recognize Indonesia's independence. ${ }^{59}$

The story of the Arab League's pro-active stance supporting Indonesia centres on the Islamic ideals of the League's first SecretaryGeneral: 'Abd al-Raḥmān 'Azzām, commonly called Azzam Pasha. Azzam Pasha was born in Egypt in 1893 and raised there, but he travelled throughout the Arab world as a young man in the 1920s and 1930s, including time in exile in Libya and as an Egyptian Minister Plenipotentiary between Iraq, Syria, and Saudi Arabia. ${ }^{60}$ He strongly supported the creation of the Arab League as a unifying body between the several Arab states emerging into independence after the Second World War --in fact, he supported a stronger vision of the union than the loose body that was created, which verged dangerously on being a mere

56 Ibid, p. 148.

57 "Sessions in October and November 1946," in Anita L.P. Burdett, ed., The Arab League: British Documentary Sources, 1943-1963, vol. 4 (London: Archive Editions and the Foreign Office of Great Britain, 1995), p. 692.

${ }^{58}$ Egyptian Society of International Law, 138. Cf. 5.37, "International Relations: Recognition of Indonesia Proposed, 1947: Abdul Rahman Azzam to Sir W. Smart, 27 February 1947 (FO 371/61518)," in Burdett (ed.), The Arab League, vol. 5, p. 744.

59 The role of the Arab League was recognized only much later by Indonesian diplomats, like the country's chief negotiator with the Dutch, Mohamad Roem. Roem stopped over in Cairo in 1968 to read in the collection of the Arab League about the organization's support for Indonesia's independence. See George McTurnan Kahin Papers, no. 14-27-3146. Division of Rare and Manuscript Collections, Cornell University Library, Box 7, "Mohamad Roem Correspondence." I am grateful to Prof. Audrey R. Kahin for making this collection available to me.

${ }^{60}$ Ralph M. Coury, The Making of an Egyptian Arab Nationalist: The Early Years of Arzam Pasha, 1893-1936 (Reading: Ithaca Press, 1998), p. 15 and passim. 
debating society. His own vision for pan-Arab unity was built on the idea of pan-Islamism (thus pushing even beyond the Islamic brotherhood message of the Indonesian student groups), as laid out in his major work, The Eternal Message of Muhammad. ${ }^{61}$

In this and other writings, Azzam Pasha made it clear that his understanding of Islam led him to condemn colonialism in the strongest terms. He identified it as the aim "underlying world evils" and the cause of suffering for the majority of the world's population. ${ }^{62}$ In fact, Azzam even put out a pamphlet in the name of the Arab League using Islamic principles to condemn imperialism. In the conclusion, he wrote, "It is a religious duty of all Moslems to condemn Imperialism. It is a great and honourable task for every Arab, true to faith and manly tradition to oppose it. A new day of peace and hope will dawn upon this tortured world only when every one of us, conqueror or conquered alike, realizes that Imperialism is a barrier to world stability and peace." ${ }^{63}$ Azzam Pasha also pushed the idea of Islamic brotherhood in his own writings, such as when he described his vision for Islamic international relations: "We pray that people will awaken to guidance, that they will discover in Islamic principles the means for establishing international relations on a basis other than that of colonialism, and that this new attitude will rest on the Islamic spirit of brotherhood." ${ }^{64}$

These intertwined ideas of pan-Islamism, anti-colonialism, and Islamic brotherhood were clearly motivating factors for Azzam Pasha's actions to support Indonesian independence. When the Arab League voted to recognize Indonesian sovereignty, Azzam Pasha was quoted in the New York Times pointing to shared histories of suffering under colonialism but also "strong religious and cultural ties with the Indonesian people." ${ }^{65}$

Azzam Pasha's actions supporting Islamic solidarity and panIslamic ideas were not universally welcome in or beyond the Arab League.

61 'Abd-al-Rahman 'Azzam, The Eternal Message of Muhammad, trans. by Caesar E. Farah and Ezzeddin Ibrahim (London: Quartet Books, 1979). This book was first published in Arabic in 1946, then with an expanded edition in 1954 that included a chapter on the state in the Islamic world.

${ }^{62}$ Ibid., p. 217.

63 Abdul-Rahman Azzam, Imperialism: The Barrier to World Peace (Cairo: Government Press, 1947), p. 12.

64 "Azzam, The Eternal Message, p. 220.

65 "Arabs Hail Indonesians: League of Seven States Votes to Recognize New Republic", The New York Times (19 Nov 1946). 
Non-Muslims in the Arab world, particularly in Lebanon, worried that Azzam Pasha was more interested in giving a pan-Islamic rather than pan-Arab character to the League. ${ }^{66}$ European powers still active in the Middle East felt very uncomfortable with his ideology and his demeanour, as one British diplomat in Iraq wrote in 1947: "Azzam is most unpopular here for his arrogance, his irresponsible actions, and his tendency to exploit the Arab League for personal ends." ${ }^{\prime 67}$

Despite these reservations about Azzam Pasha, his support was very effective at pushing the Indonesian issue onto the agenda of the Arab League, with key diplomatic consequences. This action on Indonesia set a precedent for the Arab League to work as a bloc in diplomatic affairs in the United Nations, and Azzam Pasha identified cooperation on the Indonesia question as one of the building-blocks for the later creation of the Asia-Africa bloc. ${ }^{68}$ This also paved the way for direct Indonesian relations with individual Arab states, relations that were sometimes (although not always) based on Islam.

\section{E. An Arab League Delegation to Indonesia, and State-to-State Relations}

The year 1947 was a crucial turning point in the Indonesian Revolution, especially in Indonesian diplomacy. The Islamicallybased contacts with the Arab League led to three major diplomatic milestones: the first foreign diplomatic delegation to visit the Indonesian revolutionary capital; the participation of an Indonesian delegation at a major international diplomatic conference; and the first foreign treaties recognizing Indonesian independence.

The first foreign diplomatic visit to the Republic of Indonesia was initiated by Azzam Pasha in Cairo. In January 1947, he informed the British government that he would be sending a representative of the Arab League to Indonesia and asked for British facilities to ease the sending of such an envoy. ${ }^{69}$ The British were alarmed and dismayed

66 "Criticism of Abdul Rahman Azzam" in Burdett (ed.), The Arab League, p. 399.

67 "Criticism of the Secretary-General of the Arab League, Abdul Rahman Azzam, 1947: British Embassy, Baghdad to Foreign Secretary, 3 March 1947," in Ibid., 4: 418.

${ }^{68} \mathrm{He}$ is quoted on this point in Egyptian Society of International Law, Egypt and the United Nations, pp. 73-4.

69 "International Relations: Recognition of Indonesia Proposed, 1947: Sir R. Campbell, Cairo to Foreign Office, 8 January 1947, and response, 13 January 1947," in Burdett (ed.), The Arab League, 4: 739, 743. 
at this prospect, but they were not in a position to stop the initiative. ${ }^{70}$ This was particularly so because the initiative to send a delegate was also strongly supported by Saudi Arabia, which was interested primarily because of the large number of Indonesian pilgrims who undertook the hajj every year --another Islamic connection in foreign relations that continued through to the end of the revolution. ${ }^{71}$ In February 1947, despite strong discouragement from both the British and the Dutch, Azzam Pasha felt that the Arab League was in a position to act on its own. ${ }^{72}$ By March 1947, he had arranged for the Egyptian Consul General in Bombay, Muhammad Abdul Munim, to travel to the revolutionary capital in Yogyakarta, Central Java. ${ }^{73}$

Abdul Munim made it clear during his visit to Indonesia that Islamic motivations were central in the Arab support for Indonesian independence and in prompting his visit. While in Yogyakarta, the diplomat said, "It is the Islamic brotherhood that gave rise to the support for the struggle of the Indonesian people. The spirit of Islam tells us to oppose all forms of colonialism which in essence is a practice of slavery." 74 President Sukarno's speech to honour this diplomatic guest expressed a similar sentiment, although perhaps not quite as strongly: "It is only natural that relations with Arab countries are easily made strong, because of the religious connection that already binds us together."75

This diplomatic visit was clearly both important and moving to the leadership of Indonesia, as evidenced by the actions of Vice-President Muhammad Hatta. After having pledged himself to celibacy so long as Indonesia was still under colonial rule, Hatta had finally married in

${ }^{70}$ Ibid., 4: 740.
${ }^{71}$ Ibid., 4: 739.
${ }^{72}$ Ibid., 4: 744.
${ }^{73}$ Egyptian Society of International Law, Egypt and the United Nations, p. 74, n. 6. Alternative spellings of his name include Abdel Mounem, Abdul Mun'im, and various other combinations. The record, including primary sources from various sides, is mixed as to whether he was representing Egypt, the Arab League, or both, but his travels were clearly prompted by Azzam Pasha.

${ }^{74}$ Rizal Sukma, Islam in Indonesian Foreign Policy (London: Routledge Curzon, 2003), pp. 27-8.

${ }^{75}$ Hassan, Diplomasi Revolusi, p. 194. The full speeches of both Abdul Munim and Sukarno were reprinted in the official English-language propaganda of the Republic of Indonesia: Voice of Free Indonesia, no. 62 (12 April 1947). Unfortunately, I have not been able to secure a copy of this issue. 
November 1945, months after the proclamation of independence. ${ }^{76}$ In March 1947, coinciding with the visit of Abdul Munim, he and his wife welcomed their first child into the world, a daughter whom they named Meutia Farida Hatta. The girl's middle name, Farida, was given in honour of the queen of Egypt, Queen Farida, wife of King Farouk II, as a token of gratitude that the Egyptian government had sent the first foreign diplomat to the revolutionary capital..$^{77}$

The visit of Abdul Munim was also crucial because it allowed an Indonesian diplomatic delegation to get past a Dutch blockade and exit Indonesia in March 1947, en route to their first major international summit. Apparently the Egyptian diplomat had agreed to allow members of the Indonesian delegation to join him on the flight to Singapore, but he was surprised when twenty-four individuals (still not the whole delegation) were on board --well above the plane's listed capacity. Abdul Munim justified this by saying that the Indonesian delegation "consisted of very thin and light men"; the plane made it off the runway with some difficulty, but the delegation was able to start their journey to India to attend the Asian Relations Conference in Delhi. ${ }^{78}$

Although participation in the Asian Relations Conference was a significant moment for Indonesia, the conference did not focus on the Indonesia's independence; the tenor of the meeting was general anti-colonialism and promotion of pan-Asian solidarity. Indonesia's participation increased its diplomatic profile abroad, including solidifying relations with India, a state that proved a major supporter in the United Nations. Importantly, though, Indonesia was only able to send a delegation because of the support provided by the Arab League envoy to get the diplomats past the Dutch blockade --thus again making Islamic connections critical in the development of Indonesian diplomacy. In the wake of the conference, relations with Arab states again took centre stage, as Junior Foreign Minister H. Agus Salim travelled onward from Delhi to the Middle East to engage in state-to-state diplomacy.

76 Theodore Friend, Indonesian Destinies (Cambridge: Belknap Press of Harvard University Press, 2003), p. 28.

${ }_{77}$ This was confirmed to me in a personal communication from her sister Halida Hatta, (17 Jun 2013).

${ }^{78}$ Sastroamidjojo, Milestones on My Journey, pp. 134-5; Abu Hanifah, Tales of a Revolution (Sydney: Angus and Robertson Education, 1972), p. 217. A full account of the Asian Relations conference can be found in Asian Relations, being Report of the Proceedings and Documentation of the First Asian Relations Conference, New Delbi, March-April, 1947 (New Delhi, India: Asian Relations Organization, 1948). 
In the Middle East, Salim secured the de jure recognition of the Republic of Indonesia by several Arab governments, starting with Egypt. The treaty signed on 10 June 1947, included articles to protect the friendship between the two countries with appropriate regulations to protect mutual peace and tranquillity, to establish diplomatic relations, and to agree to a temporary trade treaty, to be followed by a permanent commerce treaty soon afterward. ${ }^{79}$ Although the treaty itself makes no explicit mention of Islam or shared cultural values, the Indonesian delegate was one of the country's diplomats who was known for supporting Islamic solidarity. Salim himself was closely aligned with the Islamic party in Indonesia, Masjumi; had led the Sarekat Islam at various phases as both a social movement and political party; and had strong Islamic beliefs and experience in the Middle East dating back to his own time working in the Dutch consulate in Jeddah thirty years earlier. ${ }^{80}$ More explicit was the response by the Egyptian Prime Minister at the time, who said when receiving Salim and his delegation, "as a state based in Islam, there is no other choice [for Egypt] but to support the struggle of the Indonesian people who are also Muslim." " ${ }^{11}$ This bond was forged not only in mutual anti-colonial interests, but specifically in a context of Islamic solidarity.

After the treaty with Egypt, H. Agus Salim continued his travels around the Arab world, securing recognition in Lebanon, Syria, and Iraq in the months of June and July 1947. ${ }^{82}$ Working with other diplomats, Saudi Arabia and Yemen followed with recognition within the next year. ${ }^{83}$ All of these formal recognitions were crucial for Indonesia to prevent the Dutch from denying international status to the Indonesian conflict (especially before the UN). Indonesia did not expect military support from its new allies, but diplomatic support in seeking an internationally-

${ }^{79}$ Official copies of this treaty in Indonesian, Arabic, and French can be found in Arsip Nasional Republic Indonesia, koleksi RA3 Djodjakarta Documenten, no. 15 "Surat perjanjian persahabatan antara Republik Indonesia dengan negara kerajaan Mesir tanggal 10 Juni 1947."

${ }^{80}$ On Salim's previous time in the Middle East and his Islamic nationalism, see Laffan, Islamic Nationhood and Colonial Indonesia, pp. 181-9.

81 Sukma, Islam in Indonesian, pp. 27-8.

82 "Indonesians Form a 'Peace' Cabinet," New York Times (July 4, 1947); Leifer, "The Islamic Factor in Indonesia's Foreign Policy", pp.150-1.

83 Sukma, Islam in Indonesian, p. 27; Abu Hanifah, Tales of a Revolution, p. 263; adds to this list Afghanistan, which recognized Indonesia in September 1947. Note that this was another Islamic monarchy. 
mediated solution was at the forefront of the young state's thinking.

It is also important to note that the move towards formal relations did not mean that the tradition of activism from the Indonesian student community in Cairo was lost. The first Indonesian Ambassador to Egypt, H. M. Rasjidi, had been a student in Cairo in the 1930s, and had even served as a commissioner of Perpindom when the organization was created (at the merger of two earlier Indonesian organizations) in 1937.84 In January 1946, Rasjidi had been appointed Indonesia's first Minister of Religion, but he moved out of this role fairly soon and started working for the foreign ministry. ${ }^{85}$ When H. Agus Salim came to Cairo in 1947, Rasjidi was appointed as the official representative of the Republic of Indonesia for Egypt and Saudi Arabia. ${ }^{86}$ As of 1948, Rasjidi was the only official representative of Indonesia in the Middle East, although there were additional representative offices in Pakistan and Afghanistan. ${ }^{87}$ Nor was Rasjidi the only former student in Indonesia's new, official diplomatic office in Cairo; Fu'ad Fakhreddin, who had come from West Sumatra to Cairo to study in 1928 and had married an Egyptian woman, was absorbed into Indonesia's local diplomatic office upon its establishment. ${ }^{88}$

From 1945 and 1946, when the cause of Indonesian diplomacy in the Arab world had been led by societal initiatives by diaspora communities, Indonesia's support among Arab Muslim countries grew to concrete and formal relations in 1947. Thus, the de jure recognition that did not couch itself in Islamic terms was still built on the foundation of "Islamic brotherhood" propaganda and support from Islamically-minded politicians, and the Islamic influence in diplomacy often spilled over into the speeches or writings of these leaders. The bonds built in 1947, though,

${ }^{84}$ Jafizham, Studenten Indonesia, p. 88. For a fuller biography of Rasjidi, consult Azyumardi Azra, "Guarding the Faith of the Ummah: Religio-Intellectual Journey of Mohammad Rasjidi”, Studia Islamika, vol. 1, no. 2 (2014), pp. 87-119.

${ }^{85}$ Rasjidi's official transfer to the Ministry of Foreign Affairs was only executed in January 1948, after he had already been working with Foreign Affairs for some time. See this transfer letter signed by Sukarno in Arsip Nasional Republik Indonesia, Koleksi RA2 Sekretariat Negara RI 1945-1949, no. 574 "Presiden RI: Surat Keputusan No. 1/P.CIV / 48 tgl. 12 Januari 1948 tentang pemberhentian dengan hormat H. Rasjidi dari jabatannya sebagai Sekretaris Jenderal Kementerian Agama."

${ }^{86}$ H.M. Tahir Azhary, "In Memoriam: Almarhum Prof. Dr. H.M. Rasjidi (19152001): Birokrat Muslim, Diplomat dan Pemikir Islam”, in Bunga Rampai Hukum Islam: Kumpulan Tulisan (Jakarta: Ind Hill-Co, 2003), p. ix.

${ }^{87}$ Osman Raliby, Fragmenta Politica (Koetaradja, Atjeh: Djabatan Penerangan Atjeh, 1948), p. 199.

88 Abaza, Indonesian Students in Cairo, p. 83. 
also mark a turning point for Islam in Indonesia's formal diplomacy and for the pioneering position of Arab countries in supporting Indonesia's independence. Changes in the geo-politics of the Middle East distracted the Arab League and its members from Indonesia, and at the same time other countries and international bodies took up the Indonesian cause in their stead.

\section{F. Support on the International Stage and the Decline of Arab/ Islamic Relations}

From 1948, two changes in the international world caused a decline in the role of Arab countries in Indonesian revolutionary diplomacy. The first was the willingness of the UN and major Western powers, specifically the US, to take up the Indonesian case, making support from the Arab world less crucial. The second was a crisis on the doorstep of the Arab League, causing them to focus all attention on the Palestinian question.

The progress of international diplomacy on the world stage around Indonesia's independence has been well-documented elsewhere, ${ }^{89}$ but it is worth noting how Indonesian revolutionary diplomacy in other countries was similar to and divergent from the experience in Arab countries. In the initial stages, diplomacy was similarly conducted by self-appointed Indonesians in residence abroad, lobbying in the public sphere and calling on governments as they were able..$^{90}$ Also, across countries that had recently exited colonialism or were soon to do so, the Indonesian struggle was connected with their own struggle against a European power. This was true most notably in India, where Jawaharlal Nehru strongly criticized the Dutch in Indonesia but also the British for their role in the re-occupation of the archipelago and for their continuing colonialism in South Asia. ${ }^{91}$ Looking at South Asia, Australia, and the Arab world, Indonesian activists appealed to whatever means of solidary presented itself --anti-colonial solidarity, working class solidarity, and Islamic brotherhood, respectively-- to draw the sympathy of the general public and political leaders.

Unlike the Arab countries' move in late 1946 and 1947 to afford full de facto and de jure recognition to the Republic of Indonesia, though, other

89 The inaugural work of this literature was Taylor, Indonesian Independence; the whole progress of diplomacy leading to Indonesia's independence is also included in Kahin, alongside the narrative of the Revolution on the ground.

90 Crowl, "Indonesia's Diplomatic Revolution", p. 239.

91 Ibid., pp. 243-4. 
countries only took the intermediate step of recognizing the Republic's de facto control of certain territories on Java and Sumatra --following the lead of the Dutch who had themselves made such a concession in the Linggajati agreement of November $1946 .{ }^{92}$ Instead of focusing on direct diplomacy and recognition, countries like Australia and India instead tried to work through the new international body of the United Nations Organization. This was facilitated by the fact that the Arab countries had already recognized de jure the independence of the Indonesian state, making this a disagreement among the existing members of the United Nations and thus preventing the Dutch from blocking proposals to debate the Indonesian question. When the question was debated by countries beyond the Islamic world, of course, the theme of Islamic brotherhood was not deployed; instead, rhetoric of anti-colonialism, human rights, and justice took centre stage.

The method of internationalizing the conflict and seeking resolution through the United Nations foreshadowed the main technique deployed by decolonizing countries from the 1950s forward. The case of Algeria, where drawing in the United States, Great Britain, Spain, Egypt, and others was just as important as fighting on the ground, has been well- documented. ${ }^{93}$ The Indonesian experience differed in a number of ways, though. Indonesia was engaged in this effort before clear blocs had emerged in the UN; indeed, the Indonesian question of the 1940s has been cited by some actors as an important foundation for the later emergence of the Asia-Africa bloc. Additionally, the Netherlands was not engaged in the same kind of worldwide diplomatic push to win allies, instead focusing only on the US and European neighbours. Finally, it seems as though actors in the decolonizing world, especially Egypt and other Arab states, were acting from a more altruistic place in supporting Indonesia, as compared with the quirks of Nasser's policies in the $1950 \mathrm{~s}$ that determined the shifts in support for Morocco, Tunisia, and Algeria. ${ }^{94}$ The major similarity between the Indonesian conflict and later diplomatic efforts for other countries' decolonization, though, was the importance of internationalizing the conflict by seeking the recognition and support of other sovereign states --a policy pursued most effectively in the Arab

92 Kahin, Nationalism and Revolution, pp. 196-7; Crowl, "Indonesia's Diplomatic Revolution", pp. 244-5.

${ }^{3}$ Matthew James Connelly, Diplomatic Revolution: Algeria's Fight for Independence and the Origins of the Post-Cold War Era (Oxford: Oxford University Press, 2002).

94 Ibid., p. $100 \mathrm{ff}$. 
world and through Islamic brotherhood.

The effort to mediate the Dutch-Indonesian conflict in the United Nations accelerated after the Dutch violated the Linggajati agreement with a major military aggression (euphemized by the Dutch as a "Police Action") on July 20, $1947 .{ }^{95}$ On July 30, India and Australia each referred the Indonesian issue to the Security Council. ${ }^{96}$ That began a process leading to later treaties, greater UN involvement through the creation of a Committee of Good Offices, and eventually a Roundtable Conference where the Dutch were forced to recognize Indonesian independence and arrange for a full transfer of sovereignty in 1949.

As the case was carried to the UN by other countries, Arab and Muslim actors remained supportive, but less actively involved. In December 1948, after a second Dutch military aggression (again called by the Dutch side a "Police Action"), the Arab League called on the Security Council to step in and stop the violence. ${ }^{97}$ In March 1949, the Arab League resolved to congratulate Nehru for his work on Indonesian advocacy. ${ }^{98}$ Later that year, representatives in many Arab countries joined Nehru in New Delhi for another international affairs conference, which included a resolution against Dutch military actions. ${ }^{99}$ All of these instances were less impactful than the initial recognition of Indonesia, however, and most of them were focused on calling for action on the part of others. Azzam Pasha claimed that Egypt and the Arab League had to call for other states to take action because they had already focused their energies on Palestine. ${ }^{100}$

Indeed, the Palestinian crisis that emerged with the creation of Israel did become the overwhelming issue for Arab countries in 1948 that restrained them from continuing to be the vanguard in the diplomatic efforts to secure Indonesia's independence. From 1947, it was already clear in the speeches of the Arab delegates at the Asian Relations Conference that this was the primary international interest of the majority of their countrymen at this time. ${ }^{101}$ In many ways this topic also played on themes of Islamic solidarity, and the effort to seek resolution through

${ }^{95}$ Kahin, Nationalism and Revolution, p. 214.

${ }^{96}$ Crowl, "Indonesia's Diplomatic Revolution", p. 246.

97 "Arabs Back Indonesia", The New York Times (22 Dec 1948).

98 Egyptian Society of International Law, Egypt and the United Nations, p. 75.

99 Dipoyudo, "Indonesia's Foreign Policy", p. 476.

${ }^{100}$ Egyptian Society of International Law, Egypt and the United Nations, pp. 73-4.

101 Asian Relations, being Report of the Proceedings and Documentation of the First Asian Relations Conference, New Delhi, March-April, 1947, pp. 63-4. 
the UN was often compared to the earlier path of the Indonesian case winding its way through the Security Council, showing the importance of the Indonesian case for the Muslim world more broadly. ${ }^{102}$ As this issue rose to a boil in 1948, it was only natural that the Arab bloc could not be on the forefront of advocating for Indonesia, when all attention was focused on its own region.

Even Indonesia, despite not having attained full recognition of its independence, wanted to become involved in supporting the Palestinian cause. In 1946, Indonesia had made a major diplomatic statement with the promise to ship 500,000 tons of rice to India, as a contribution to famine relief in the subcontinent. The Indians accepted this offer enthusiastically, and even though restrictions by the Dutch (who controlled major ports) severely curtailed the shipment, the impact on international goodwill was still made. ${ }^{103}$ Hoping to build on this success, the first Indonesian ambassador to Cairo, H. Rasjidi, proposed to arrange a shipment of rice for the Palestinians in June 1948. ${ }^{104}$ By September of that year, Rasjidi was still working to arrange for the shipment, which was expanded to include both rice and sugar, but arrangements to evade the Dutch blockade were providing a great hindrance. ${ }^{105}$ It seems that the shipment never came to fruition.

The conflict in Palestine also made Arab League members more reticent to send permanent representatives to Indonesia. The Egyptian government promised the Indonesian ambassador in Cairo that it was interested in sending an ambassador to Yogyakarta, but the Egyptians feared that if the Dutch recognized Israel then the Egyptian ambassador might become a target for wartime violence. ${ }^{106}$ For this reason the Egyptians sought a resolution from the Arab League to provide diplomatic cover for sending such a permanent representative,

102 See "Truce in Palestine", The New York Times (10 Jun 1948); Clifton Daniel, "The Moslem World Watches Palestine", The New York Times (13 Jul 1948).

${ }^{103}$ Henry Knight, Food Administration in India, 1939-1947 (Stanford, CA: Stanford University Press, 1954), pp. 260-1.

104 Arsip Nasional Republik Indonesia, Koleksi RA3 "Djogdja Documenten 1945-1949," no. 306: "Surat-surat dari Perwakilan Republik Indonesia di beberapa negara," undated letter from H. Rasjidi.

105 Arsip Nasional Republik Indonesia, Koleksi RA3 "Djogdja Documenten 1945-1949," no. 306: "Surat-surat dari Perwakilan Republik Indonesia di beberapa negara," telegram from Cairo dated 3 September 1948.

${ }^{106}$ Arsip Nasional Republik Indonesia, Koleksi RA3 "Djogdja Documenten 1945-1949," no. 306: "Surat-surat dari Perwakilan Republik Indonesia di beberapa negara," letter from H. Rasjidi dated 21 September 1948. 
but no resolution was ever passed to this effect. ${ }^{107}$ The communication from Cairo in 1948 shows that the Palestinian issue eclipsed Indonesian independence as a diplomatic concern, and that the members of the Arab League no longer felt themselves in a position to stand at the forefront of efforts to support Indonesia.

Still, at the very end of the Revolution, the Indonesian government looked to the Arab countries as an important bloc for supporting their independence. As the Round Table Conference convened in the Netherlands to determine conditions for the transfer of sovereignty, the Indonesian government appointed a special bajj delegation in September 1949. Before this delegation left the Republican capital of Yogyakarta, one of its participants was reportedly instructed by Indonesian President Sukarno, "If the negotiations in Den Haag fail, the [haj] mission cannot return home to Indonesia; it must remain longer in the Arab and North African countries, with the duty to explain to their leaders and governments in those countries about the struggle of the Republic of Indonesia, so that they can help the Indonesian nation in its physical struggle as well as diplomatic struggle." ${ }^{108}$ The delegation did go to the Hijaz for a month, participating in the bajj and providing a gift to the King of Saudi Arabia, followed by two months in Cairo, where they also received Vice-President Hatta on his return journey from the successful Round Table Conference negotiations. ${ }^{109}$ The vision of this delegation carrying on the work of reaching out to Arab governments and leaders, as had been done by independent students at the start of the Revolution, presents an interesting book-end to Indonesian diplomatic activities in the Arab world. This is especially demonstrative since this bajj mission was formally sent by the government, rather than a popular movement, thus demonstrating the trend towards formalization of relations over the course of these four years.

The actions of the Indonesians were no longer eliciting major reactions in Cairo or Mecca, though, both because such reactions were no longer needed and because the Arab world was by 1949 so wrapped up in its own region. In this context, it was easy to forget the important

107 Arsip Nasional Republik Indonesia, Koleksi RA3 "Djogdja Documenten 1945-1949," no. 306: "Surat-surat dari Perwakilan Republik Indonesia di beberapa negara," letter from H. Rasjidi dated 29 September 1948; cf. Burdett (ed.), The Arab League., pp. 739-40.

108 Ali Hasjmy, Semangat Merdeka: 70 Tabun Menempub Jalan Pergolakan \& Perjuangan Kemerdekaan (Jakarta: Bulan Bintang, 1985), p. 391.

109 Ibid., pp. 389-95. 
role Arab countries had played in the initial diplomatic achievements of the young Republic of Indonesia.

\section{G. Concluding Remarks}

Building up from the history of Indonesian foreign policy in this early era, it is clear that Islam did have a prominent role, not particularly as an ideology on which to base policy or as rhetoric to justify policy to domestic audiences, but as an instrument to enact policy. Indonesia deployed Islamic connections to build its early alliances. This corrects the current literature that has seen no place for Islam in Indonesia's foreign policy.

Although Islam was crucial for policy execution in the early years of Indonesian independence, this action did not come from the newly independent government nor from government-appointed representatives. Instead, Islam was deployed by societal groups at some distance from the state (both ideologically and geographically). Perhaps it is because this action was initiated by society and not by the state that official accounts --and the scholarship that has followed official sources-have been short-sighted on the place of religion in Indonesian foreign policy.

The influence of society to increase the religious content of Indonesian foreign policy is in keeping with other Muslim-majority countries. As Brenda Shaffer found through comparative work in the Caucasus, Central Asia, and the Middle East: "In regimes where foreign policy was not controlled by a central actor, more opportunity for promotion of culturally-based interests seems to exist." The "culturallybased interest" that showed this trend most clearly was religion. ${ }^{110}$ The Indonesian case study above reinforces this finding, but also amplifies it; "culturally-based interests" such as religion are a function not only of regime structure, but also of the contingent circumstances in which foreign policy develops, and when such circumstances do not facilitate control by a central actor, religion has a stronger position in policy.

For the study of Indonesian foreign relations, demonstrating the important role of Islam in this case demands that studies moving forward must be reframed. Thus, scholars should no longer ask whether or why Islam has not been invoked or not been central, but rather why the initial

110 Brenda Shaffer, "Introduction: The Limits of Culture", in Limits of Culture: Islam and Foreign Policy, ed. by Brenda Shaffer (Cambridge, MA: MIT Press, 2006), p. 6. Al-Jāmi‘ah, Vol. 53, No. 2, 2015 M/1437 H 
Kevin W. Fogg

use of Islam was later jettisoned in favour of entirely secular international relations, and how social groups differ from the Indonesian government in presenting the country abroad. This also has implications for how the young Indonesian government perceived itself in emerging networks of newly sovereign states; the roots of the non-aligned movement need to be seen as Islamic, especially in connecting Indonesia with the Arab world, in addition to anti-colonial or anti-Western. Finally, the initial success of societal groups in the Middle East and their subsequent decline should remind scholars to consider contingency in the evaluation of foreign policy shifts.

Looking beyond foreign policy, this case should prompt scholars to think differently about the role of Islam in the state. Although studies have already pointed toward the increased strength of Islam in society and the growing place of Islam in government since the fall of Soeharto, ${ }^{111}$ they have not connected the turn towards Islam with a decrease in central state power. As early foreign policy demonstrates, the greater strength of society vis-à-vis the state --as Indonesia has seen since 1998-- provides a more likely environment for religious influences on policy, often carried by societal actors.

Indonesia is not now, nor has it been historically, as religiously neutral as its state rhetoric presents the country. ${ }^{112}$ Instead, Islam has had a role that ebbs and flows in relation to the strength of society to promote this religious interest, in foreign policy or other manifestations.

111 Ricklefs, Islamisation and Its Opponents in Java.

112 Jeremy Menchik, "Productive Intolerance: Godly Nationalism in Indonesia", Comparative Studies in Society and History, vol. 56, no. 3 (2014), pp. 591-621. 


\section{BIBLIOGRAPHY}

Abaza, Mona, Islamic Education: Perceptions and Exchanges: Indonesian Students in Cairo, Cahier d'Archipel no. 23, Paris: Association Archipel, 1994.

Abu Hanifah, Tales of a Revolution, Sources of Modern Indonesian History and Politics series, number 1, Sydney: Angus and Robertson, 1972.

“Akoeilah Repoeblik Indonesia: Desakan sk di Mesir", Lasjkar, 11 Nov 1946.

Anwar, Dewi Fortuna, "Foreign Policy, Islam and Democracy in Indonesia", Journal of Indonesian Social Sciences and Humanities vol. 3 (2010), pp. 37-54.

“Arabs Back Indonesia, New York Times, 22 Dec 1948.

"Arabs Hail Indonesians: League of Seven States Votes to Recognize New Republic", New York Times, 19 Nov 1946.

Arsip Nasional Republik Indonesia, Koleksi RA2, Sekretariat Negara RI 1945-1949, no. 574: "Presiden RI: Surat Keputusan No. 1/P.CIV/ 48 tgl. 12 Januari 1948 tentang pemberhentian dengan hormat H. Rasjidi dari jabatannya sebagai Sekretaris Jenderal Kementerian Agama.”

Arsip Nasional Republik Indonesia, Koleksi RA3, Djogdjakarta Documenten 1945-1949, no. 306: "Surat-surat dari Perwakilan Republik Indonesia di beberapa negara."

Arsip Nasional Republik Indonesia, koleksi RA3, Djogdjakarta Documenten 1945-1949, no. 15: "Surat perjanjian persahabatan antara Republik Indonesia dengan negara kerajaan Mesir tanggal 10 Juni 1947."

Asian Relations Organization, Asian Relations, being Report of the Proceedings and Documentation of the First Asian Relations Conference, New Delhi, March-April, 1947, New Delhi: Asian Relations Organization, 1948.

Azhary, H. M. Tahir, "In Memoriam: Almarhum Prof. Dr. H.M. Rasjidi (1915-2001): Birokrat Muslim, Diplomat dan Pemikir Islam”, in Bunga Rampai Hukum Islam, Jakarta: Ind-Hill-Co, 2003.

Azra, Azyumardi, "Guarding the Faith of the Ummah: The Religiointellectual Journey of Mohammad Rasjidi", Studia Islamika, vol. 1 no. 2 (1994) [http://dx.doi.org/ 10.15408/sdi.v1i2.859].

----, "Islam in Indonesian Foreign Policy", in Indonesia, Islam and Democracy: Dynamics in a Global Context, Jakarta: Solstice, 2006. 
Kevin W. Fogg

Azzam, Abd al-Rahman, "The Arab League and World Unity", reprinted in Anouar Abdel Malek (ed.), Contemporary Arab Political Thought, trans. Michael Pallis, London: Zed Press, 1983.

----, The Eternal Message of Muhammad, trans. Caesar E. Farah, London: Quartet Books, 1979.

----, "Imperialism: The Barrier to World Peace", Arab League Pamphlets on International Relations, no. 1, Cairo: Government Press, 1947.

Bondan, Mohamad, Genderang Proklamasi di Luar Negeri, Jakarta: KAWAL, 1971.

Bondan, Molly, Spanning a Revolution: The Story of Mohamad Bondan and the Indonesian Nationalist Movement, Jakarta: Pustaka Sinar Harapan, 1992.

"Britain and Egypt", New York Times, 6 Apr 1946.

Burdett, Anita L. P. (ed.), The Arab League: British Documentary Sources, 1943-1963, London: Archive Editions and the Foreign Office of Great Britain, 1995.

Bush, Robin, "Regional Sharia Regulations in Indonesia: Anomaly or Symptom?", in Greg Fealy and Sally White (eds.), Expressing Islam: Religious Life and Politics in Indonesia, Singapore: ISEAS, 2008.

Connelly, Matthew, Diplomatic Revolution: Algeria's Fight for Independence and the Origins of the Post-Cold War Era, Oxford: Oxford University Press, 2002.

Coury, Ralph M, The Making of an Egyptian Arab Nationalist: The Early Years of Azzam Pasha, 1893-1936, Reading: Ithaca Press, 1998.

Crowl, Samuel E, “Indonesia’s Diplomatic Revolution: Lining Up for Non-Alignment, 1945-1955", in Connecting Histories: Decolonization and the Cold War in Southeast Asia, 1945-1962, Stanford, CA: Stanford University Press and the Woodrow Wilson Center, 2009.

Daniel, Clifton, "The Moslem World Watches Palestine", New York Times, 13 Jun 1948.

Dipoyudo, Kirdi, "Indonesia's Foreign Policy towards the Middle East and Africa", The Indonesian Quarterly, vol. 13, no. 4, 1985.

Egyptian Society of International Law, Egypt and the United Nations, New York: Manhattan Publishing Company for the Carnegie Endowment for International Peace, 1957.

Elson, R. E., “Absent at the Creation: Islamism's Belated, Troubled Engagement with Early Indonesian Nationalism", in Anthony Reid 
and the Study of the Southeast Asian Past, Singapore: ISEAS, 2012.

Feener, R. Michael, "New Networks and New Knowledge: Migrations, Communications and the Refiguration of the Muslim community in the Nineteenth and Early Twentieth Centuries", in New Cambridge History of Islam, vol. 6, Cambridge: Cambridge University Press, 2010.

Fogg, Kevin William, The Fate of Muslim Nationalism in Independent Indonesia, Ph.D. Thesis, Yale University, 2012.

Friend, Theodore, Indonesian Destinies, Cambridge, MA: Belknap Press, 2003.

Gardner, Paul F., Shared Hopes, Separate Fears: Fifty Years of U.S.-Indonesia Relations, Boulder, CO: Westview, 1997.

George McTurnan Kahin Papers, no. 14-27-3146, Division of Rare and Manuscript Collections, Cornell University Library, Box 7, "Mohamad Roem Correspondence."

Gouda, Frances and Thijs Brocades Zaalberg, American Visions of the Netherlands East Indies/Indonesia: US Foreign Policy and Indonesian Nationalism, 1920-1949, Amsterdam: Amsterdam University Press, 2002.

Hasjmy, Ali, Semangat Merdeka: 70 Tahun Menempuh Jalan Pergolakan \& Perjuangan Kemerdekaan, Jakarta: Bulan Bintang, 1985.

Hassan, M. Zein, Diplomasi Revolusi Indonesia di Luar Negeri, Jakarta: Bulan Bintang, 1980.

Hefner, Robert W, Civil Islam: Muslims and Democratization in Indonesia, Princeton, NJ: Princeton University Press, 2000.

Ho, Engseng, The Graves of Tarim: Genealogy and Mobility across the Indian Ocean, Berkeley, CA: University of California Press, 2006.

Ichwan, Moch Nur, "Differing Responses to an Ahmadi Translation and Exegesis: The Holy Qur'ân in Egypt and Indonesia", Archipel, vol. 62, No. 1, 2001.

Ide Anak Agung Gde Agung, Twenty Years Indonesian Foreign Policy 19451965, The Hague: Mouton, 1973.

“Indonesians Form a 'Peace' Cabinet”, New York Times, 4 Jul 1947.

Jafizham, Tengkoe, Studenten Indonesia di Mesir, Medan: Sinar Deli, 1939.

Kahin, George McTurnan, Nationalism and Revolution in Indonesia, Ithaca, NY: Cornell University Press, 1952. 
Kevin W. Fogg

Khadduri, Majid, "The Arab League as a Regional Arrangement", The American Journal of International Law, vol. 40, no. 4, 1946 [http:// dx.doi.org/10.2307/2193821].

Knight, Henry, Food Administration in India, 1939-1947, Stanford, CA: Stanford University Press for the Stanford University Food Research Institute, 1954.

Laffan, Michael Francis, Islamic Nationhood and Colonial Indonesia: The Umma Below the Winds, London: Routledge, 2003.

Landau, J. M., "Pan-Islamism”, Encyclopaedia of Islam, Leiden: Brill, 2014.

Leifer, Michael, "The Islamic Factor in Indonesia's Foreign Policy: A Case of Functional Ambiguity", Islam in Foreign Policy, Cambridge: Cambridge University Press, 1983.

McMahon, Robert J., Colonialism and Cold War: The United States and the Struggle for Indonesian Independence, 1945-49, Ithaca, NY: Cornell University Press, 1981.

Menchik, Jeremy, "Productive Intolerance: Godly Nationalism in Indonesia", Comparative Studies in Society and History, vol. 56, no. 3, 2014 [http://dx.doi.org/10.1017/s0010417514000267].

Mobini-Kesheh, Natalie, The Hadrami Awakening: Community and Identity in the Netherlands East Indies, 1900-1942, Ithaca, NY: Cornell University Southeast Asia Program, 1999.

"Nasib Poetera2 Indonesia di Mesir dan Arab”, Lasjkar, 25 Jul 1946.

Noer, Deliar, The Modernist Muslim Movement in Indonesia, 1900-1942, Singapore: Oxford University Press, 1973.

Perwita, Anak Agung Banyu, Indonesia and the Muslim World: Islam and Secularism in the Foreign Policy of Soeharto and Beyond, Copenhagen: NIAS Press, 2007.

Pitsuwan, Surin, The ASE AN Community 2015: Challenges and Opportunities for the Muslims of Southeast Asia, Lecture at Oxford University, Oxford, 28 January 2013.

Raliby, Osman (ed.), Fragmenta Politica, Koetaradja, Atjeh: Djabatan Penerangan Atjeh, 1948.

Reinhardt, Jon M., Foreign Policy and National Integration: The Case of Indonesia, New Haven, CT: Yale University Southeast Asia Studies, 1971.

Ricklefs, M.C., Islamisation and Its Opponents in Java: A Political, Social, Cultural and Religious History, c. 1930 to the Present, Singapore: NUS Press, 2012. 
Roadnight, Andrew, United States Policy towards Indonesia in the Truman and Eisenhower Years, New York: Palgrave, 2002.

Roff, William R., "Indonesian and Malay students in Cairo in the 1920s", Indonesia, vol. 9, 1970 [http://dx.doi.org/10.2307/3350623].

Sastroamijoyo, Ali, Milestones on My Journey: The Memoirs of Ali Sastroamijoyo, Indonesian Patriot and Political Leader, St. Lucia, Queensland: University of Queensland Press, 1979.

Shaffer, Brenda, "Introduction: The Limits of Culture", in Brenda Shaffer (ed.), Limits of Culture: Islam and Foreign Policy, Cambridge, MA: MIT Press, 2006.

Snouck Hurgronje, Christiaan, Mekek in the Latter Part of the $19^{\text {th }}$ Century, trans. J. H. Monahan, Leiden: Brill, 2007 [1931].

Soedarpo, Mien, Reminiscences of the Past, volume II, ed. Siti Nuraini Barnett, Jakarta: Sejati Foundation with PT Gramedia Widiasarana Indonesia, 1997.

Sukma, Rizal, Islam in Indonesian Foreign Policy, London: Routledge Curzon, 2003.

Tagliacozzo, Eric, The Longest Journey: Southeast Asians and the Pilgrimage to Mecca, Oxford: Oxford University Press, 2013.

Taylor, Alastair M., Indonesian Independence and the United Nations, London: Stevens \& Sons, 1960.

"Truce in Palestine", New York Times, 10 Jun 1948. 